\title{
Pengelolaan Anestesi untuk Eksisi Tumor Intradura Intramedula (IDIM) Setinggi Vertebra Cervical 5-6 dengan Panduan Intraoperative Neurophysiological Monitoring
}

\author{
Dhania A. Santosa*), Bambang Harijono*), Hamzah*), Zafrullah K. Jasa**), Nancy Margarita Rehatta*) \\ ${ }^{*}$ Departemen Anestesiologi dan Reanimasi Fakultas Kedokteran Universitas Airlangga-RSUD Dr. Soetomo \\ Surabaya, ${ }^{* *}$ Departemen Anestesiologi dan Terapi Intensif Fakultas Kedokteran Universitas Syahkuala - RSUD \\ dr. Zainoel Abidin Aceh
}

\begin{abstract}
Abstrak
Eksisi tumor intradura intramedula (IDIM) dengan bantuan intraoperative neurophysiological monitoring (IOM) merupakan suatu teknik pembedahan yang bertujuan agar eksisi tumor dilakukan semaksimal mungkin, dengan meminimalkan defisit neurologis akibat pembedahan. Penanganan anestesi pada eksisi tumor IDIM dengan bantuan IOM ini, seorang ahli anestesi perlu menguasai ilmu dan keterampilan neuroanestesi untuk pembedahan tulang belakang, selain itu juga pemilihan teknik, jenis dan dosis obat yang mendukung pelaksanaan pembedahan dengan IOM ini. Seorang laki-laki usia 52 tahun dengan tumor IDIM setinggi vertebra cervical 5-6 menjalani pembedahan eksisi tumor dengan bantuan IOM. Pembedahan dilakukan di bawah pengaruh anestesi umum dengan induksi intravena. Laringoskopi dilakukan dengan video laryngoscope. Pembedahan dilakukan dengan panduan IOM, selama anestesi diberikan total intravenous anesthesia tanpa pemberian pelumpuh otot tambahan setelah intubasi. Pembedahan berlangsung selama enam jam dan tumor dapat terangkat seluruhnya. Tantangan selama periode perioperatif adalah penilaian dan persiapan prabedah yang teliti, posisi pasien dan pemilihan teknik anestesi yang tepat.
\end{abstract}

Kata kunci: eksisi tumor, tumor IDIM, IOM, penanganan anestesia

JNI 2018;7(3): 164-74

\section{Anesthesia Management for Cervical 5-6 Intradural Intramedullary (IDIM) Tumor under Intraoperative Neurophysiological Monitoring Guidance}

\begin{abstract}
Excision of intradural intramedullary (IDIM) tumor using intraoperative neurophysiological monitoring (IOM) is one surgical technique aiming to excise tumor as maximum as possible, with minimum neurological deficit. In anesthesia management for IDIM tumor excision under IOM guidance, an anesthesiologist is required to master neuroanesthesia knowledge and skill, especially for spine surgery. Moreover, understanding the art of anesthesia technique, drug and dose supporting surgery with IOM. A male patient, 52 years old, with IDIM tumor at the level of cervical 5-6th underwent surgery for tumor excision using IOM. Surgery was done under general anesthesia, started with intravenous induction, and intubation was done using video laryngoscope. Surgery was done under IOM guidance, total intravenous anesthesia was implemented and no additional muscle relaxant was given after intubation. Surgery lasted for six hours and tumor was resected completely. Challenges during perioperative period are meticulous preoperative assessment and preparation, patient positioning and appropriate anesthesia technique.
\end{abstract}

Key words: tumor excision, IDIM tumor, IOM, anesthesia management 


\section{Pendahuluan}

Tumor intradura intramedula (IDIM) merupakan neoplasma yang jarang terjadi, hanya $2-4 \%$ dari seluruh tumor sistem saraf pusat. ${ }^{1}$ Pembedahan untuk eksisi tumor IDIM masih membawa risiko yang cukup signifikan untuk kerusakan akibat pembedahan yang pada akhirnya menyebabkan disfungsi neurologis. Pada awalnya, karena defisit neurologis pascabedah cukup signifikan, banyak ahli bedah saraf merekomendasikan strategi konservatif dengan biopsi, cangkok dura dan terapi radiasi, apa pun diagnosis histologisnya. ${ }^{1}$ Seiring dengan berjalannya waktu, terjadi kemajuan pesat dalam teknik pencitraan saraf dan bedah mikro, sehingga modalitas terapi kemudian bergeser menuju ke arah pembedahan sebagai modalitas utama. Namun demikian, pembedahan untuk tumor IDIM tetap merupakan suatu tugas yang menantang. Alasan digunakannya intraoperative neurophysiological monitoring (IOM) adalah untuk memenuhi target reseksi tumor maksimal dengan morbiditas neurologis yang minimal. ${ }^{1}$

Saat ini, penggunaan kombinasi somatosensory evoked potential (SSEP) dan motor evoked potential (MEP) pada pembedahan tumor IDIM hampir menjadi suatu kewajiban karena kemungkinannya mendeteksi cedera secara selektif baik pada jalur somatosensorik maupun motorik. ${ }^{1}$ Tantangan bagi ahli anestesi dalam melakukan anestesi pada pembedahan untuk eksisi tumor IDIM dengan IOM tidaklah ringan. Ahli anestesi dituntut memiliki kejelian dalam melakukan evaluasi prabedah yang menyeluruh; bukan hanya untuk menilai kondisi pasien secara umum tetapi juga hal-hal khusus yang terjadi pada pasien dengan patologi pada tulang belakang. Selain itu, ahli anestesi juga dituntut untuk menguasai dan menerapkan dengan baik teknik neuroanestesi pada pembedahan tulang belakang. ${ }^{2}$ Hal yang spesifik tentunya dalam hal penggunaan IOM selama pembedahan adalah pemilihan teknik, jenis dan dosis obat anestesi yang digunakan agar dapat mendukung terlaksananya pembedahan dengan baik agar tujuan akhir dapat tercapai.

\section{Kasus}

Seorang laki-laki berusia 52 tahun, berat badan 54 $\mathrm{kg}$, dengan tetraparese tipe upper motor neuron (UMN) et causa tumor intra dura intra medulla (IDIM) setinggi vertebra C5-6 dilakukan eksisi tumor dengan Intraoperative Monitoring (IOM).

\section{Anamnesis}

Pasien mengeluh kedua tangan dan tungkai melemah sejak 7 bulan yang lalu. Kedua kaki pasien juga terasa tebal. Pada saat pasien dirawat di rumah sakit, pasien hanya bisa berbaring. Tidak ada riwayat trauma sebelumnya. Pasien memiliki riwayat hipertensi dengan terapi amlodipine 10 mg satu kali sehari per oral.

\section{Pemeriksaan Fisik}

Pada pemeriksaan prabedah didapatkan pasien dengan kondisi jalan napas bebas, dengan pernapasan spontan torakal adekuat 16 kali per menit, gerak dada simetris, suara napas vesikuler kanan dan kiri, tidak terdapat suara napas tambahan. Pulse oximetry terbaca $97 \%$ dengan $\mathrm{O}_{2}$ udara bebas $\left(\mathrm{FiO}_{2} 21 \%\right)$. Pada perabaan didapatkan perfusi hangat, kering dan merah, dengan capillary refill time kurang dari 2 detik. Tekanan darah 140/90 dan MAP $107 \mathrm{mmHg}$ dan nadi 87 kali per menit, nadi radialis teraba teratur dan kuat angkat. Skor GCS E4V5M6, pupil bulat isokor diameter $3 \mathrm{~mm}$ dengan refleks cahaya positif kanan dan kiri. Pada pemeriksaan kekuatan motorik pasien didapatkan hasil yaitu sampai dengan setinggi C7 kekuatan motorik $5 / 5$, selanjutnya setinggi $C 81 / 2$ dan setinggi Th1 1/1. Sedangkan kekuatan motorik dari L2 ke bawah 3/2. Sedangkan pada pemeriksaan sensorik didapatkan normal pada ekstremitas atas dan menurun pada kedua ekstremitas bawah. Dari pemeriksaan refleks fisiologis didapatkan +2 pada ekstremitas atas kanan dan kiri dan +4 pada ektremitas bawah kanan dan kiri. Pada pasien ini tidak didapatkan inkontinesia urine maupun inkontinensia alvi.

\section{Pemeriksaan Penunjang}

Hemoglobin 13,5 g/dL, Hematokrit 42,6\%, Leukosit 4.810/mm3, Trombosit $154.000 \mu \mathrm{L}$. PPT 10,4 (kontrol 9-12), aPTT 27,3 (kontrol 
23-33). Natrium $139 \mathrm{mEq} / \mathrm{L}$, Kalium 3,8 $\mathrm{mEq} / \mathrm{L}$, Chlorida $106 \mathrm{mEq} / \mathrm{L}$, gula darah acak $97 \mathrm{mg} / \mathrm{dL}$. BUN $10 \mathrm{mg} / \mathrm{dL}$, kreatinin serum $0,8 \mathrm{mg} / \mathrm{dL}$, SGOT $18 \mu / \mathrm{L}$, SGPT $21 \mu / \mathrm{L}$. Dari pemeriksaan analisa gas darah dengan oksigen udara bebas didapatkan hasil $\mathrm{pH} 7,41, \mathrm{pCO}_{2} 39$, $\mathrm{pO}_{2}$ 157, $\mathrm{HCO}_{3}-24,7, \mathrm{BE} 0,3, \mathrm{SaO}_{2} 99 \%$. Dari pemeriksaan foto toraks didapatkan cor prominen dengan Cardio Thoracic Ratio (CTR) 50\% dan paru dalam batas normal. Dari pemeriksaan elektrokardiografi (EKG) didapatkan hasil irama sinus 80 kali per menit, aksis LAD, tanpa tanda iskemia maupun blok.

Dari pemeriksaan MRI cervical dengan kontras didapatkan homogenous enhancing solid mass intradura intramedula setinggi C5-6 dengan syringomyelia setinggi vertebra C4-5 dan C7Th2, kemungkinan besar spinal ependymoma, selain itu didapatkan bone marrow edema pada vertebra C6.

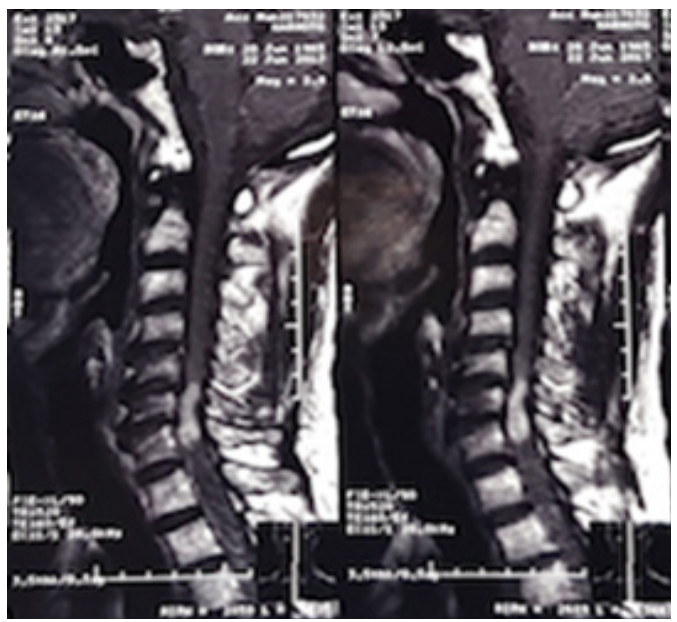

Gambar 1. MRI cervical dengan kontras didapatkan homogenous enhancing solid mass intradura intramedulla setinggi C5-6 dengan syringomyelia setinggi vertebra C4-5 dan C7Th2, kemungkinan besar spinal ependymoma dan didapatkan bone marrow edema pada vertebra $\mathrm{C} 6$.

Pengelolaan Anestesi

Selama persiapan untuk pembedahan elektif, pasien dipuasakan dan diberikan cairan infus berupa $\mathrm{NaCl} \quad 0,9 \% \quad 80 \mathrm{~mL} / \mathrm{jam}$. Kondisi pasien sebelum induksi anestesi adalah: tekanan darah 120/80 mmHg, MAP $93 \mathrm{mmHg}$ dengan nadi 100 kali per menit reguler kuat angkat di arteri radialis. Skor GCS E4V5M6 dengan pupil bulat isokor diameter $3 \mathrm{~mm}$ mata kanan dan kiri. Pasien tanpa distress napas dengan pulse oximetry $99 \%$ tanpa suplemen oksigen. Sebelum masuk kamar operasi, pasien diberi premedikasi midazolam $2 \mathrm{mg}$ intravena. Induksi dilakukan dengan obat-obatan anestesi sebagai berikut: midazolam $3 \mathrm{mg}$, fentanyl $50 \mathrm{mcg}$, lidocaine $60 \mathrm{mg}$, propofol $100 \mathrm{mg}$ dan atracurium $25 \mathrm{mg}$ intravena kemudian dilakukan laringoskopi dengan video laryngoscope dan intubasi dengan pipa endotrakhea (endotracheal tube) non kink no. 7,5 dan difiksasi. Selama pembedahan dilakukan dengan rumatan propofol $75-200 \mathrm{mg} / \mathrm{jam}$ dan dexmedetomidine $\quad 0,2-05 \quad \mathrm{mcg} / \mathrm{kg} \quad \mathrm{BB} /$ menit. Kemudian dilakukan persiapan pemasangan IOM dan setelahnya pasien diposisikan prone. Pada awal pembedahan, dilakukan pemasangan lateral mass screw di vertebra $\mathrm{C} 5,6,7$ dan dilakukan total laminektomi pada vertebra $\mathrm{C} 5,6,7$. Setelah

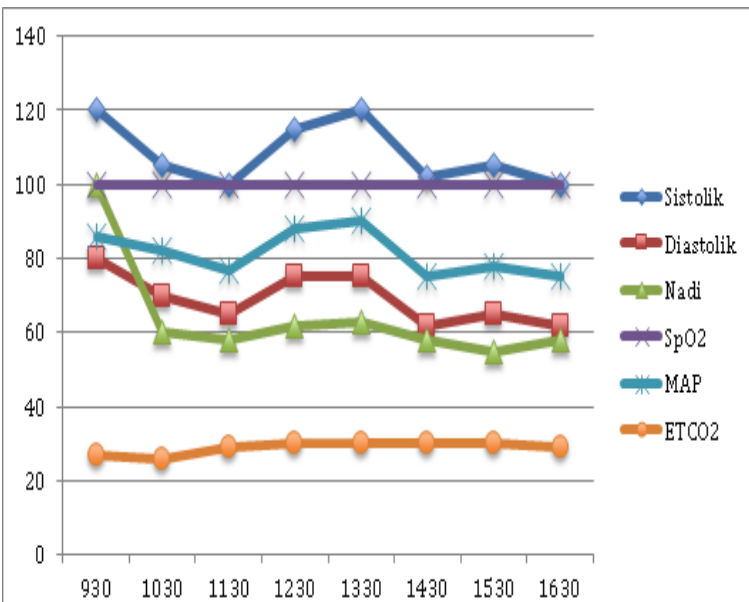

Grafik 1. Kondisi Hemodinamik Pasien selama Pembedahan

dilakukan insisi arachnoidmater, dilakukan identifikasi midline myelum dan dilakukan insisi. Tampak massa kemerahan, dilakukan diseksi tumor dan dipisahkan dari myelum. Dilakukan identifikasi pole atas dan bawah tumor dan dievaluasi dengan IOM. Dilakukan debulking tumor dan dapat terangkat seluruhnya. Setelahnya dilakukan evaluasi akhir neurofungsional dengan IOM, dilakukan pemasangan drain kemudian 
Pengelolaan Anestesi untuk Eksisi Tumor Intradura Intramedula (IDIM) Setinggi Vertebra Cervical 5-6 dengan Panduan Intraoperative

ditutup. Selama pembedahan tekanan darah berkisar 100-120/62-80 mmHg dengan MAP 75-90 mmHg. Nadi berkisar antara 55-100 kali per menit dan pulse oximetry $100 \%$. Pembedahan berlangsung kurang lebih selama 6 jam dengan keseimbangan cairan yaitu input $\mathrm{NaCl}$ 0,9\% 500 $\mathrm{mL}$, ringerfundin $500 \mathrm{~mL}$. Perkiraan perdarahan $300 \mathrm{~mL}$, produksi urine selama pembedahan 300 $\mathrm{mL}$.

\section{Pengelolaan Pascabedah}

Pasca bedah pasien diobservasi di ICU dengan dukungan ventilator mekanik. Setelah pasien sadar baik dilakukan pemeriksaan neurologis dan setelah napas adekuat kemudian dilakukan ekstubasi. Perfusi hangat kering merah dengan tekanan darah 112/78, MAP 89 mmHg. Nadi 61 kali per menit suhu timpanik $36,2^{\circ} \mathrm{C}$. Produksi urine $50 \mathrm{~mL} / \mathrm{jam}$. Terapi yang diberikan di antaranya ringerfundin $1500 \mathrm{~mL} / 24$ jam, injeksi ondansetron 3 x $4 \mathrm{mg}$ iv, omeprazole 1 x $40 \mathrm{mg}$ iv, paracetamol $3 \times 1 \mathrm{~g}$ iv, fentanyl bila VAS $>$ 3 dan dexmedetomidine $0,1 \mathrm{mcg} / \mathrm{kg} / \mathrm{jam}$ sampai dengan 24 jam pasca bedah. Hasil pemeriksaan laboratorium pascabedah di antaranya $\mathrm{Hb} 11,1$ $\mathrm{g} / \mathrm{dL}$, hematokrit $32,9 \%$, leukosit $10.080 / \mathrm{mm} 3$, trombosit $134.000 \mu \mathrm{L}$.

Pasien kemudian diekstubasi pada pagi hari pertama pascabedah. Kondisi pasien setelah ekstubasi adalah sebagai berikut: jalan napas bebas dengan pernapasan spontan 15-16 kali per menit, suara nafas vesikuler kedua lapang paru tanpa suara napas tambahan, pulse oximetry terbaca $100 \%$ dengan suplemen nasal prong 2 lpm. Tekanan darah 131/77 mmHg dengan MAP $95 \mathrm{mmHg}$. Nadi 68 kali per menit, teraba reguler dan kuat angkat pada arteri radialis. Suhu timpanik $36,8^{\circ} \mathrm{C}$. Kondisi kesadaran pasien dengan GCS E4 V5 M6 dengan pupil bulat isokor $3 \mathrm{~mm}$ mata kanan dan kiri dan refleks cahaya positif. Pasien kemudian dipindahkan ke ruangan perawatan biasa pada hari pertama pascabedah.

\section{Pembahasan}

Seorang laki-laki berusia 52 tahun, berat badan 54 $\mathrm{kg}$, dengan tetraparese tipe upper motor neuron (UMN) et causa tumor intradura intramedulla
(IDIM) setinggi vertebra C5-6 dilakukan eksisi tumor dengan Intraoperative Monitoring (IOM). Tumor medulla spinalis IDIM merupakan neoplasma yang jarang ditemui, hanya sekitar $2-4 \%$ dari seluruh tumor sistem saraf pusat. $^{1}$ Tumor IDIM muncul di suatu tempat antara perbatasan cervicomedula sampai dengan filum terminale dari medula spinalis dan umumnya menyebabkan defisit neurologis yang berat. ${ }^{2}$ Dari semua tumor IDIM, ependymoma adalah yang paling sering $(60-70 \%)$ diikuti oleh astrositoma (30-40\%). ${ }^{2}$ Tumor IDIM lainnya yang lebih jarang terjadi di antaranya hemangioblastoma, metastase dan limfoma. ${ }^{2}$

Pembedahan untuk eksisi tumor IDIM membawa risiko terjadinya kerusakan akibat pembedahan yang pada akhirnya menyebabkan disfungsi neurologis. ${ }^{1}$ Kemajuan teknologi telah menggeser modalitas terapi tumor IDIM. Hal ini terlihat dari perubahan terapi tumor IDIM yang dahulu berupa strategi konservatif dengan biopsi, cangkok dura dan terapi radiasi, apapun diagnosis histologisnya, sedangkan saat ini terapi radiasi hanya dilakukan untuk tumor yang muncul kembali atau ganas. ${ }^{1}$ Sebagian besar tumor IDIM sifatnya jinak ${ }^{3}$ dan oleh karenanya eksisi tumor total berakibat pasien dapat bertahan hidup dalam jangka panjang, ${ }^{4}$ sehingga pada akhirnya perlu melakukan pembedahan yang 'aman'. Bagaimanapun, pembedahan pada neoplasma ini tetap memberikan tantangan dan latar belakang penggunaan monitoring neurofisiologi intraoperatif(IOM) adalah untuk memaksimalkan reseksi tumor dan meminimalkan morbiditas neurologi. IOM oleh karenanya tidak hanya diharapkan dapat memprediksi defisit neurologis pascabedah, tetapi, yang paling penting, dapat mengidentifikasi cedera yang mungkin terjadi pada medula spinalis pada waktu yang tepat sehingga dapat diambil tindakan korektif.

Pasien ini adalah seorang laki-laki yang masih berada pada usia produktif dengan jenis tumor yang dicurigai ependymoma yang sifatnya jinak. Oleh karena itu, pasien ini tentu akan sangat terbantu dan kualitas hidupnya sangat mungkin membaik bila teknik pembedahan eksisi sebanyak mungkin tanpa menimbulkan defisit neurologis 
Tabel 1. Pemeriksaan Prabedah yang Dianjurkan sebelum Pembedahan Tulang Belakang Mayor

\begin{tabular}{lll}
\hline & Pemeriksaan minimal & Pemeriksaan opsional \\
\hline Jalan napas & $\begin{array}{l}\text { Foto polos cervical lateral dengan } \\
\text { tampilan fleksi/ekstensi (untuk } \\
\text { pasien dengan artritis rematoid) }\end{array}$ & \\
Sistem pernapasan & Foto polos dada & $\begin{array}{l}\text { Tes faal paru (bronchodilator } \\
\text { reversibility) }\end{array}$ \\
& Analisa gas darah & Kapasitas difusi paru \\
Sistem Kardiovaskular & Elektrokardiografi & Ekokardiografi dobutamine-stress \\
& Ekokardiografi & Dypiridamole/thallium \\
& & scintigraphy \\
Pemeriksaan darah & Darah lengkap fungsi liver \\
& Faal hemostasis & \\
& Cross match darah & \\
& Urea, elektrolit & \\
& Albumin, kalsium & (penyakit \\
& neoplastic) & \\
\hline
\end{tabular}

Disadur dari Raw DA, Beattie JK, Hunter JM. Anaesthesia for spinal surgery in adults. Br J Anaesth 2003; 91: 886-904.

baru dapat berhasil. Pada kasus ini keputusan untuk dilakukan eksisi tumor dengan bantuan IOM sangat tepat. Tugas ahli anestesi dalam hal ini selain menguasai dan aplikasi teknik neuroanestesi untuk pembedahan tulang belakang, tentunya adalah mendukung pelaksanaan penggunaan IOM. Penilaian prabedah untuk pasien yang akan menghadapi pembedahan tulang belakang, perhatian khusus harus diberikan pada sistem pernapasan, kardiovaskular dan neurologi; yang mana ketiganya dipengaruhi oleh kondisi patologis tulang belakang yang akan dilakukan pembedahan. ${ }^{5}$ Selain itu perlu dilakukan diskusi yang menyeluruh dengan ahli bedah mengenai jenis pembedahan yang akan dilakukan dan kemungkinan perdarahan yang terjadi serta stabilitas tulang belakang. ${ }^{6}$ Potensi kesulitan pengelolaan jalan napas harus selalu dipertimbangkan, khususnya pada pasien yang akan menjalani pembedahan cervical atau torakal atas. Penilaian yang teliti harus dilakukan untuk riwayat kesulitan intubasi, keterbatasan gerak leher dan stabilitas cervical. Stabilitas didefinisikan sebagai kemampuan tulang belakang, dengan beban fisiologis mampu menahan terjadinya pergeseran yang dapat menyebabkan cedera neurologis. 5 Selain itu, modalitas penilaian lainnya seperti klasifikasi Mallampatti, pergerakan leher, bukaan mulut dan lainnya harus juga dinilai. ${ }^{6}$ Vertebra cervical dapat dinilai secara klinis (adanya nyeri atau defisit neurologis) dan secara radiografi (foto polos lateral atau fleksi/ekstensi, CT scan dan MRI). Stabilitas vertebra cervical bergantung pada elemen ligamen dan vertebra. Hancurnya elemen-elemen ini mungkin tidak terdeteksi dengan foto polos saja. Pada akhirnya harus diputuskan apakah pasien akan diintubasi dalam kondisi awake atau asleep. Evaluasi jalan napas pada pasien ini diprediksi tidak sulit mengingat walaupun tumor terletak pada vertebra cervical, tetapi vertebra cervical dalam kondisi stabil, selain itu juga gerak leher pasien tidak mengalami keterbatasan, sedangkan penilaian jalan napas lainnya dalam batas normal. Namun demikian kemungkinan terjadi cedera pada saat manuver laringoskopi dan intubasi tentu harus dipikirkan dengan baik. Pasien yang akan dilakukan pembedahan tulang belakang sering mengalami gangguan fungsi pernapasan. Pasien yang mengalami trauma pada cervical atau torakal tinggi atau dengan banyak cedera mungkin sudah diventilasi mekanik sebelum pembedahan. Pasien-pasien lain mungkin mengalami infeksi 
Pengelolaan Anestesi untuk Eksisi Tumor Intradura Intramedula

Tabel 2. Masalah Terkait Posisi Telungkup ${ }^{12}$

\begin{tabular}{|c|c|}
\hline Potensi Masalah & Keterangan \\
\hline \multicolumn{2}{|l|}{ Mata } \\
\hline Abrasi korena & Pastikan mata tertutup dan diplester \\
\hline \multirow[t]{3}{*}{ Neuropati optik } & Peningkatan tekanan intraokuler \\
\hline & Penurunan tekanan perfusi \\
\hline & $\begin{array}{l}\text { Kurangi risiko dengan menghindari penekanan pada mata, hipotensi, } \\
\text { hematokrit rendah }\end{array}$ \\
\hline Oklusi arteri renalis & Hindari penekanan pada mata \\
\hline Kepala dan Leher & $\begin{array}{l}\text { Pasien diposisikan dengan hati-hati untuk meminimalisir sumbatan aliran } \\
\text { vena }\end{array}$ \\
\hline Fiksasi kepala & $\begin{array}{l}\text { Insersi pin pada kepala dapat menyebabkan respons hipertensi yang sulit } \\
\text { dikendalikan }\end{array}$ \\
\hline Penekanan abdomen & Hindari penekanan abdomen \\
\hline Gangguan ventilasi output & Bantal lebih baik dibandingkan rangka pendukung atau posisi knee chest \\
\hline \multicolumn{2}{|l|}{$\begin{array}{l}\text { Kerusakan pada pembuluh darah } \\
\text { besar }\end{array}$} \\
\hline \multirow[t]{2}{*}{ Aorta dan vena cava } & $\begin{array}{l}\text { Kerusakan yang tidak disengaja setelah terjadi perforasi ligamentum } \\
\text { longitudinal anterior dapat menyebabkan perdarahan hebat. Tekanan darah } \\
\text { mendadak turun dan terjadi disosiasi elektromekanik }\end{array}$ \\
\hline & Mortalitas tinggi \\
\hline Pembuluh darah iliaca & $\begin{array}{l}\text { Kondisi menurun lebih perlahan. Kewaspadaan yang tinggi dapat } \\
\text { menghindari terjadinya diagnosis yang terlambat }\end{array}$ \\
\hline
\end{tabular}

Disadur dari Samantaray A. Anaesthesia for spine surgery. The Indian Anaesthetists' Forum 2006; Online ISSN 0973-0311.

paru yang berulang. Pada pemeriksaan prabedah, fungsi pernapasan harus dinilai mulai dari anamnesis yang teliti, berfokus pada gangguan fungsi, pemeriksaan fisik dan pemeriksaan tambahan yang diperlukan (tabel 1). Prinsipnya, selama masa prabedah, semua kondisi yang reversible harus dikoreksi, seperti, mengendalikan infeksi paru dengan antibiotika yang adekuat dan optimalisasi kondisi paru dengan fisioterapi napas dan bronkodilator. ${ }^{6}$ Pasien yang berisiko tinggi membutuhkan ventilasi mekanik pasca bedah di antaranya adalah pasien dengan kapasitas vital 30-35\% lebih rendah dari nilai prediksi, prabedah sudah menggunakan ventilasi mekanik dan pasien yang memerlukan tekanan jalan napas positif lewat hidung pada waktu malam hari. ${ }^{6}$ Secara klinis, pemeriksaan prabedah terhadap kondisi sistem pernapasan pasien ini cukup baik. Pernapasan pasien dalam kondisi dominan torakal dengan gerak naik-turunnya dada cukup adekuat, 16 kali per menit. Pada pemeriksaan analisa gas darah juga dapat dipastikan tidak terdapat gangguan ventilasi dan oksigenasi pada pasien serta pada pemeriksaan foto toraks juga didapatkan paru dalam kondisi bersih dan tidak infeksi. Namun demikian apabila dilengkapi dengan pemeriksaan faal paru atau minimal spirometri pada pasien ini tentu lebih baik sehingga dapat diperoleh gambaran mengenai kondisi pasien dengan lebih detil. Kondisi awal pasien ini memberikan gambaran bahwa dukungan ventilasi mekanik pascabedah pada pasien ini seharusnya tidak perlu berlangsung terlalu lama.

Evaluasi sistem kardiovaskular penting untuk melihat ada tidaknya disfungsi jantung yang diakibatkan langsung oleh patologi primer yang terjadi, khususnya pada pasien dengan distrofi otot dan skoliosis. Profilaksis tromboemboli penting pada pembedahan tulang belakang karena risiko terjadinya besar mengingat waktu pembedahan lama, posisi prone, keganasan dan kemungkinan tirah baring lama setelah pembedahan. 
Direkomendasikan untuk menggunakan compression stocking dan/atau pneumatic boots. ${ }^{5}$ Penggunaan antikoagulan dikaitkan dengan komplikasi perdarahan, termasuk peningkatan perdarahan dan hematom epidural. ${ }^{5}$ Pemeriksaan kardiovaskular pada pasien ini sebaiknya dilengkapi dengan ekokardiografi, mengingat bahwa pasien ini ada riwayat penyakit penyerta yaitu hipertensi. Walaupun tampaknya tidak terlalu parah, namun kemungkinan hipertensi berlangsung cukup lama, terlihat dari gambaran EKG yang sudah ada gambaran pergeseran aksis jantung ke arah kiri. Sehingga bila dilakukan pemeriksaan ekokardiografi maka gambaran mengenai kondisi jantung pasien tentunya dapat lebih jelas. Hal ini penting sebagai modal untuk menghadapi kondisi selama dan setelah pembedahan yang mungkin mengalami gejolak hemodinamik baik karena kondisi medula spinalisnya sendiri maupun dari manuver pembedahan.

Pemeriksaan neurologis lengkap harus dilakukan pra bedah. Hasil pemeriksaan ini harus didokumentasikan untuk tiga alasan. Alasan pertama, pasien yang menjalani pembedahan cervical, ahli anestesi bertanggungjawab untuk menghindari perburukan kondisi neurologis lebih jauh selama manuver intubasi dan pemosisian pasien. Alasan kedua, distrofi otot mungkin melibatkan otot-otot bulbar sehingga meningkatkan risiko aspirasi pascabedah. Alasan ketiga, tingkat ketinggian cedera dan waktu yang berlalu sejak kejadian merupakan prediktor gangguan fisiologis pada sistem kardiovaskular dan pernapasan yang terjadi pada periode perioperatif. Bila pembedahan dilakukan dalam 3 minggu setelah cedera, syok spinal mungkin masih ada. Setelah periode waktu ini, dapat terjadi disrefleksia otonom. ${ }^{5}$ Penggunaan obat bronkodilator mungkin berguna untuk mengoptimalisasi fungsi pernapasan prabedah. Pada pasien dengan lesi medula spinalis yang tinggi, atau pada pasien yang akan dilakukan intubasi dengan fiber-optic, pemberian obat antikolinergik seperti atropine atau glikopirolat harus dipertimbangkan. Banyak pasien yang memiliki faktor-faktor yang meningkatkan risiko regurgitasi dan aspirasi isi lambung, seperti pemberian opioid, cedera medula spinalis tinggi atau cedera traumatik yang baru terjadi. ${ }^{7}$ Dalam kondisi-kondisi seperti ini, penting untuk memberikan premedikasi pasien dengan antagonis reseptor histamine-2 atau proton pump inhibitor. Beberapa pasien mungkin menggunakan pipa nasogastrik, yang dapat menurunkan kompetensi sfinkter esophagus atas.

Secara umum, induksi menggunakan pelumpuh otot berdurasi pendek, dilanjutkan dengan pemberian kontinu propofol dan fentanyl serta dosis kecil nitrous oxide (tidak lebih dari 50\%) penting untuk monitoring Motor Evoked Potential (MEP). Pada pemerikaan prabedah harus diputuskan apakah intubasi dilakukan dalam kondisi awake atau asleep dan apakah laringoskopi dengan fiber-optic mungkin diperlukan. Pasien harus diberitahu mengenai keputusan intubasi ini. Terdapat kontroversi apakah laringoskopi direk dapat memperburuk cedera neurologis pada pasien dengan vertebra cervical yang tidak stabil, namun demikian kontribusi faktor lain seperti hipotensi dan posisi pasien juga sama pentingnya. ${ }^{8}$ Laringoskopi direk dengan stabilisasi in-line manual atau dengan hard collar dapat dilakukan pada banyak pasien karena dapat dilakukan tanpa menggerakan leher. Deformitas fleksi yang kaku, yang melibatkan vertebra cervical dan torakal atas membuat laringkopi direk tidak mungkin dilakukan. Pada pasien ini dapat dilakukan laringoskopi fiberoptic atau dengan intubating LMA. ${ }^{5}$

Beberapa studi telah dilakukan untuk membandingkan laringoskop Macintosh dengan laringoskop Bullard, ventilasi dengan masker, combitube esophagus, LMA, intubating LMA dan intubasi nasal dengan panduan fiber optic atau intubasi oral dalam hal pergerakan vertebra cervical dan disimpulkan bahwa intubasi fiber optic adalah metode intubasi yang menyebabkan paling sedikit gerakan pada vertebra cervical. ${ }^{6}$ Namun demikian, beberapa studi belakangan menyatakan bahwa penggunaan video laryngoscope pada pasien dengan vertebra cervical yang tidak stabil ternyata merupakan alternatif yang baik bila tidak tersedia fiber optic. ${ }^{9}$ Penggunaan dexmedetomidine perioperatif tidak 
Pengelolaan Anestesi untuk Eksisi Tumor Intradura Intramedula (IDIM) Setinggi Vertebra Cervical 5-6 dengan Panduan Intraoperative

hanya memberikan efek sedasi dan analgesia tetapi juga memberikan kestabilan hemodinamik perioperatif dan hilangnya episode menggigil secara signifikan. ${ }^{10,11}$ Indikasi untuk intubasi awake termasuk risiko pengosongan lambung lambat, perlunya menilai neurologi setelah intubasi dilakukan (pada kasus di mana tulang vertebra cervical tidak stabil) atau adanya alat stabilisasi leher (traksi halo) yang tidak memungkinkan rumatan jalan napas yang adekuat pada pasien yang tidak sadar. Bila tidak, induksi intravena diikuti dengan obat pelumpuh otot nondepolarisasi merupakan teknik terpilih. ${ }^{5}$

Intubasi awake dengan fiber-optic diperlukan untuk pasien yang mengenakan alat stabilisasi semacam rompi halo, yang menyebabkan akses jalan napas konvensional tidak mungkin dan pada pasien yang diperkirakan akan sulit intubasi karena alasan anatomis, misalnya mikrognatia, bukaan mulut yang kecil. Pada pasien dengan vertebra cervical yang tidak stabil, pemberian anestesi lokal pada jalan napas untuk membantu intubasi awake dapat menyebabkan batuk hebat. Pada kasus demikian, lebih baik menggunakan lidokain yang dinebulisasi dibandingkan injeksi krikotiroid atau pemberian anestesi lokal melalui fiber-optic scope. Pada pasien ini diputuskan untuk melakukan intubasi dengan teknik asleep apneu dengan pertimbangan kondisi vertebra cervical yang stabil, namun demikian teknik laringoskopi yang dipilih adalah dengan video laryngoscope, hal ini didasari atas pertimbangan bahwa dengan bantuan video laryngoscope, pergerakan vertebra cervical selama laringoskopi cukup minimal sehingga diharapkan tidak menambah cedera neurologi akibat manuver laringoskopi. Setelah dilakukan induksi, pasien diposisikan telungkup (prone). Ada beberapa hal yang harus diwaspadai terkait posisi telungkup ini, terutama karena pembedahan tulang belakang umumnya berjalan cukup lama. ${ }^{9}$

Yang perlu menjadi perhatian adalah risiko kerusakan medula spinalis. Kerusakan neurologis selama pembedahan dan anestesia tidak hanya terbatas pada tempat pembedahan. Paraplegia dan quadriplegia juga telah dilaporkan sebagai hasil pemosisian pasien yang buruk. Risiko ini terkait dengan lama dan jenis pembedahan, tekanan perfusi medula spinalis, patologi medula spinalis yang mendasari dan tekanan pada jaringan saraf selama pembedahan. Risiko ini dapat diminimalkan dengan pemosisian yang baik, menjaga tekanan perfusi medula spinalis, pemberian methylprednisolone kurang dari 8 jam setelah cedera, antagonis NMDA (ketamine, magnesium) dan pencegahan pembentukan bekuan darah (pengendalian perdarahan yang baik, penghentian obat anti-platelet sebelum pembedahan dan tunda pembedian heparin segera setelah pembedahan). ${ }^{12}$

Posisi pasien untuk pembedahan cervical umumnya kaki dekat dengan mesin anestesi. Hal ini memungkinkan akses pembedahan terhadap kepala dan leher. Perlu diperkirakan keperluan perpanjangan sirkuit pernapasan dan jalur intravena dan mungkin perlu memasang kanula intravena pada kaki pasien. Pipa trakea harus diamankan sedemikian rupa tanpa mengganggu lapangan pembedahan. Penting untuk menempatkan kepala pada alas yang lunak dan menjaga agar mata, nervus orbita superior dan kulit di sekitar maxila agar tidak mengalami cedera iskemia, yang bisa terjadi bila pemosisian pasien tidak tepat. Monitor standar digunakan selama pembedahan yaitu elektrokardiografi, pengukur tekanan darah non invasif, pulse oximetry, kapnograf dan temperatur. Monitoring khusus seperti pengukur tekanan darah arteri, tekanan vena sentral dan produksi urine bergantung lama prosedur, kemungkinan kehilangan banyak cairan, risiko emboli udara vena, riwayat penyakit pasien, kondisi hemodinamik tidak stabil prabedah (syok spinal) dan teknik anestesi khusus seperti hipotensi terkendali dan pembedahan endoskopik. ${ }^{12}$

Terapi cairan selama pembedahan medula spinalis pada dasarnya sama dengan penanganan cairan pada pasien bedah saraf lainnya yaitu mempertahankan normovolemia dan menghindari penurunan osmolaritas serum yang dapat berujung pada edema otak. ${ }^{13}$ Selama prosedur medula spinalis yang menggunakan IOM, idealnya dilakukan monitoring terhadap baik -somatosensory evoked potentials (SSEP) 
maupun motoric evoked potential (MEP) mengingat kemungkinan terjadinya cedera selektif hanya pada jalur somato sensorik saja atau jalur motorik saja. ${ }^{1}$ Baik SSEP maupun MEP dipengaruhi oleh berbagai faktor farmakologis dan fisiologis. Obat atau parameter fisik yang mempengaruhi konduksi listrik sepanjang akson dapat merubah bentuk gelombang evoked potential. ${ }^{13}$ Secara umum, makin panjang dan makin banyak sinaps, sebuah traktus akan makin sensitif. Lebih jauh lagi, lebih mudah untuk mendapatkan sinyal dari ekstremitas atas dibanding ekstremitas bawah. Hal ini disebabkan karena area tangan menempati representasi lebih besar pada korteks motorik. ${ }^{14}$

Teknik anestesi konvensional dengan obat anestesi volatil berhalogen dapat mengganggu SSEP15 dan MEP1 tergantung dosis pada tingkat korteks dan spinal. ${ }^{2}$ Hal ini disebabkan karena obat anestesi inhalasi mengurangi amplitudo dan meningkatkan latensi, sedangkan obat anestesi intravena memiliki efek yang sama tetapi dengan tingkat yang lebih rendah. ${ }^{13}$ Obat anestesi berhalogen atau berbasis nitrous oxide mempengaruhi amplitudo dan latensi SSEP. ${ }^{13}$ MEP secara umum lebih sensitif terhadap obat anestesi dibanding SSEP. ${ }^{13}$

Pemberian kontinu propofol (umumnya dosis 100-150 mcg $/ \mathrm{kg} / \mathrm{menit}$ ) dan fentanyl (umumnya sekitar $1 \mathrm{mcg} / \mathrm{kg} / \mathrm{jam}$ ) dapat digunakan untuk rumatan. ${ }^{1}$ Dosis diatur sedemikian rupa sehingga tekanan darah yang dimonitor secara invasif berada pada kisaran normotensi (kisaran MAP 70-100 $\mathrm{mmHg})^{2}$ atau ketika pasien belum ditidurkan dan dalam posisi telentang. ${ }^{15}$ Pelumpuh otot berdurasi pendek dapat diberikan untuk intubasi tapi tidak setelahnya sehingga memungkinkan monitoring MEP. ${ }^{1,15}$ Pasien juga dipertahankan normotermi selama pembedahan. ${ }^{2}$ Selama pembedahan pada pasien ini, rumatan dilakukan dengan pemberian kontinu propofol dan dexmedetomidine. Hal ini dilakukan atas pertimbangan propofol pada kisaran dosis tertentu tidak terlalu banyak mengganggu SSEP dibandingkan anestesi inhalasi sehingga hal ini mendukung kelancaran reseksi tumor seradikal mungkin tetapi tetap menjaga terkontrol dengan
IOM. Selain itu pelaksanaan pembedahan dengan IOM didukung oleh tidak diberikannya pelumpuh otot rumatan, tetapi hanya diberikan pada awal saja untuk memfasilitasi intubasi. Pemberian dexmedetomidine dalam hal ini agar dapat menjadi sparring terhadap propofol sehingga dosis propofol tidak terlalu besar yang dapat berefek pada kondisi hemodinamik pasien dan SSEP pada IOM. Selain itu pemberian dexmedetomidine pada pasien ini diteruskan sampai dengan pascabedah di ICU selama pasien dalam proses pemulihan dalam dukungan ventilasi mekanik. ${ }^{11}$

Anestesia hipotensi mungkin digunakan untuk membuat lapangan pembedahan lebih baik dan mengurangi kehilangan darah selama pembedahan tulang belakang mayor. Beberapa teknik di antaranya obat anestesi volatil, calcium channel blocker, sodium nitroprusside, nitogliserin. MAP dijaga pada kisaran $60 \mathrm{mmHg}$. MAP umumnya tidak dibiarkan di bawah 60 mmHg karena pada titik ini SSEP tidak dapat terdeteksi dan cedera iskemia dapat terjadi. ${ }^{5}$ Terdapat hanya sedikit bukti menunjukkan obat mana yang lebih superior, tetapi menghindari takikardia adalah bagian penting untuk teknik anestesia yang baik. ${ }^{5}$ Propofol memberikan efek penekanan yang kuat pada cortical evoked responses, menyebabkan pengurangan yang bergantung pada dosis pada amplitude respons. Dosis bolus propofol $2 \mathrm{mg} / \mathrm{kg}$ dapat menghilangkan MEP cortical. ${ }^{11}$ Obat anestesi volatil juga mempunyai efek menekan cortical evoked MEP yang kuat. Midazolam dan etomidat menyebabkan reduksi amplitudo respons yang adekuat tetapi lebih kecil. Opioid seperti fentanyl juga dilaporkan mengurangi amplitudo respons atau tidak berefek. ${ }^{16}$ Pada akhirnya pemberian kontinu propofol dan fentanyl atau remifentanil memberikan perekaman MEP yang adekuat pada $97 \%$ pasien yang secara neurologis intak. ${ }^{17}$ Komplikasi pascabedah dini setelah pembedahan tulang belakang mayor di antaranya adalah kurang cairan, difungsi neurologis, cedera dura sehingga terjadi kebocoran cairan serebrospinal, mual, muntah, atelektasis, pneumonia dan thrombosis vena. ${ }^{6}$ Proses ekstubasi dapat sulit dilakukan dan sebaiknya dilakukan ketika pasien sadar dan 
Pengelolaan Anestesi untuk Eksisi Tumor Intradura Intramedula

dapat mempertahankan jalan napasnya sendiri. Namun demikian, salah satu komplikasi yang mungkin terjadi pascabedah di antaranya adalah sumbatan jalan napas pasca ekstubasi. Rentannya jalan napas pascabedah ini dapat terjadi karena adanya bekuan darah atau defisit neurologis. Sedasi dan ventilasi pascabedah sebaiknya tidak dipertahankan telalu lama karena dapat mengaburkan gejala dan tanda penurunan kondisi neurologis pascabedah. Oleh karenanya keputusan untuk melakukan ekstubasi atau mempertahankan sedasi dan ventilasi mekanik pascabedah harus melalui pertimbangan keuntungan dan kerugian yang matang dan telah dilakukan persiapan untuk mengantisipasi apa pun konsekuensi dari pilihan yang diambil. Perawatan pascabedah pada pasien ini dilakukan di ICU dengan sedasi dan dukungan ventilasi mekanik sampai dengan dapat dilakukan evaluasi kesadaran dan fungsi neurologi, kemudian dilakukan ekstubasi. Hal ini didasari pertimbangan agar pasien pulih sadar secara perlahan dan bertahap dalam pengawasan ketat.

\section{Simpulan}

Eksisi tumor IDIM dengan bantuan IOM merupakan suatu modalitas pembedahan yang dapat mengurangi defisit neurologis akibat pembedahan. Teknik pembedahan ini bertujuan agar tumor terambil sebanyak mungkin tanpa membuat defisit neurologis baru. Pendekatan pembedahan ini menuntut ahli anestesi tidak hanya menguasai ilmu dan keterampilan neuroanestesi untuk pembedahan tulang belakang saja, tetapi juga teknik anestesi untuk memungkinkan dilakukannya monitoring IOM selama pembedahan.

\section{Daftar Pustaka}

1. Sala F, Bricolo A, Faccioli F, Lanteri P, Gerosa M. Surgery for intramedullary spinal cord tumors: the role of intraoperative (neurophysiological) monitoring. Eur Spine J 2007; 16 (Suppl 2): S130-S139.

2. Tiruchelvarayan $\mathrm{R}$, Tang $\mathrm{MH}$, Perera $\mathrm{S}$, Lo YL. Outcomes following aggressive surgical resection of intra-medullary spinal cord tumours with intra-operative neuromonitoring. Proceedings of Singapore Healthcare 2013; 22(3): 183-90.

3. Constantini S, Miller DC, Allen JC, Rorker LB, Freed D, Epstein FJ. Radical excision of intramedullary spinal cord tumors: Surgical morbidity and long-term follow up evaluation in 164 children and young adults. J Neurosurg (Spine) 2000; 93:183-193

4. Epstein FJ, Farmer J-P, Freed D. Adult intramedullary spinal cord ependymoma: the result of surgery in 38 patients. J Neurosurg 1993; 79: 204-09.

5. Raw DA, Beattie JK, Hunter JM. Anaesthesia for spinal surgery in adults. Br J Anaesth 2003; 91: 886-904.

6. Bajwa SJ, Kuslrestha A. Spine surgeries: challenging aspects and implications for anaesthesia. J Spine Neurosurg 2013; 2(3): $1-8$.

7. Engelhardt T, Webster NR. Pulmonary aspiration of gastric contents in anaesthesia. Br J Anaesth 1999; 83: 453-60.

8. McLeod AD, Calder I. Spinal cord injury and direct laryngoscopy - the legend lives on. $\mathrm{Br}$ J Anaesth 2000; 84: 705-09.

9. Bathory I, Frascarolo P, Kern P, Schoettker P. Evaluation of the GlideScope for tracheal intubation in patients with cervical spine immobilization by a semi-rigid collar. Anaesthesia 2009; 64: 1337-41.

10. Bajwa SJ, Kaur J, Singh A, Parmar SS, Singh G, Kulshrestha A, dkk. Attenuation of pressor response and dose sparing of opioids and anaesthetics with pre-operative dexmedetomidine. Indian J Anaesth 2012; 56: 123-28.

11. Bajwa SJ, Gupta S, Kaur J, Singh A, Parmar $\mathrm{S}$. Reduction in the incidence of shivering 
with perioperative dexmedetomidine: A randomized prospective study. J Anaesthesiol Clin Pharmacol 2012; 28: 86-91.

12. Samantaray A. Anaesthesia for spine surgery. The Indian Anaesthetists' Forum 2006; Online ISSN 0973-0311.

13. Park JH, Hyun SJ. Intraoperative neurophysiological monitoring in spinal surgery. World J Clin Cases 2015; 3(9): 76573.

14. Deiner S. Highlights of anesthetic considerations for intraoperative neuromonitoring. Semin Cardiothorac Vasc Anesth 2010; 14: 51-3.
15. Brotchi J, Bruneau M, Lefranc F, Baleriaux D. Surgery of intraspinal cord tumor. Clinical Neurosurgery 2006; 53: 209-16.

16. Kalkman CJ, Drummond JC, Ribberink AA, Patel PM, Sano T, Bickford RG. Effects of propofol, etomidate, midazolam and fentanyl on motor evoked responses to transcranial electrical or magnetic stimulation in humans. Anesthesiology 1992; 76: 502-09.

17. Pelosi L, Stevenson M, Hobbs GJ, Jardine A, Webb JK. Intraoperative motor evoked potentials to transcranial electrical stimulation during two anaesthetic regimens. Clin Neurophysiol 2001; 112: 1076-87. 